\title{
Nationality, Ethnicity, and Solidarity: Respon Turki atas Perundingan Etnis Uighur
}

\author{
Moh. Fathoni Hakim, Denimah, Devy Febrian Arisandy \\ Bahtiar, Muhammad Zulfikar Ramadhan, Feryan \\ Airlangga, dan Stefano Jalu Sambowo Putra \\ UIN Sunan Ampel Surabaya
}

\begin{abstract}
Abstrak
Masyarakat Uighur berasal dari keturunan klan Turkestan yang sejak lama telah mendiami Kawasan Asia Tengah dan Asia Barat. Sebagai minoritas di wilayah barat laut Republik Rakyat Tiongkok, keberadaan kelompok etnik ini kerap kali mendapatkan stigma negatif dari negara. Mereka acapkali dicap sebagai kelompok separatis. Suasana menjadi semakin keruh pasca terjadinya demonstrasi besar-besaran pada 2009 yang berujung rusuh antara etnis Uighur dan etnis Han di provinsi Xinjiang. Sebagai negara yang memiliki ikatan primordial dengan etnis Uighur, Turki lantas merespon isu diskriminasi yang terjadi. Dengan demikian, masalah ini berpotensi membawa ketegangan hubungan antara Turki dan Tiongkok. Menggunakan kerangka diplomasi bilateral, tulisan ini hendak mengkaji sejauh mana respon yang diberikan pemerintah Turki terhadap isu kekerasan etnik di Xinjiang. Hasil analisis menyatakan bahwa isu Uighur senantiasa membayangi hubungan bilateral Turki-Tiongkok semenjak kemunculannya. Meskipun menimbulkan kerenggangan, kedua belah pihak masih tetap melangsungkan hubungan dengan relatif baik.
\end{abstract}

Kata kunci: Uighur; Turki; Tiongkok; Diplomasi Bilateral; Hubungan Bilateral

Uighur is an ethnic group which originally come from the Turkestan clan, which is predominantly found in Central and Western Asia Regions. As a minority within the People's Republic of China northwestern region, Its existence often sparks negative stigma from the China government. They are labelled as separatist groups. Large-scale demonstrations in 2009, which eventually led to riots between Uighur and Han Chinese population in Xinjiang, managed to worsen the situation. As a country that has primordial ties with the Uighur, Turkey has responded to the issue of discrimination that befell the Uighur. Therefore, this problem could bring tension to both Turkey and China. Utilizing the concept of bilateral diplomacy, this paper aims to examine the extent of the Turkish government's response to the issue of ethnic violence in Xinjiang. The findings show that the Uighur issue has always overshadowed Turkey-China bilateral relations ever since Its rise. Despite the disagreement, both have maintained a relatively good relation.

Keywords: Uighurs; Turkey; China; Bilateral Diplomacy; Bilateralism 


\section{Pendahuluan}

Tersebar umumnya di kawasan Asia Tengah dan Barat, etnis Uighur adalah suku minoritas terbesar yang resmi diakui oleh Tiongkok. Agama Islam-lebih spesifiknya Islam Sunni tradisional moderat-menjadi agama yang dianut oleh kelompok etnis ini dan mereka. Komponen ini bahkan teresap dalam kultur Uighur; ditunjukan dalam sejumlah cerita rakyat dan tradisi penduduk pedesaan yang tinggal di daerah oasis tersebut (Human Rights Watch Report 2005). Di Tiongkok, domisili etnis Uighur terpusat di daerah otonomi Xinjiang (XUAR). Kebudayaan Mongol-Turki cukup mendominasi di wilayah ini sejak abad ke-IX. Lantas, tidak mengherankan apabila penduduknya merupakan hasil campuran dari bangsa-bangsa tersebut dengan Tiongkok.

Seiring dengan berjalannya waktu, populasi Uighur yang cukup dominan di daerah XUAR mulai terkikis oleh kehadiran populasi Han Tiongkok sebagai akibat dari maraknya imigrasi ke wilayah tersebut (Congressional Research Service Report 2020). Gesekan kultural ini pun lambat-laun berevolusi menjadi sentimen penentuan nasib sendiri. Hal ini termanifestasi pada dekade 30-an dan 40-an, ketika etnis Uighur dan beberapa kelompok etnis muslim setempat mendirikan Republics of Eastern Turkestan di Kashgar (1933) dan Ili (1944) sebagai bentuk resistensi terhadap pemerintahan Tiongkok. Meski kedua republik itu berumur pendek, peristiwa tersebut terus menginspirasi berbagai oposisi nasionalis sejak 1949, khususnya di kalangan Uighur.

Selama empat dekade berikutnya, kontrol yang kuat dari otoritas Partai Komunis di Xinjiang telah meminimalisir segala potensi separatisme etnis di daerah ini. Namun bagi kebanyakan etnis Uighur, harapan dan sentimen untuk memiliki negara sendiri tidak sepenuhnya pudar (Chung 2002). Memasuki era yang lebih kontemporer, Kerusuhan Urumqi tahun 2009 merupakan peristiwa besar yang melibatkan etnis Uighur dan etnis Han Tiongkok. Kericuhan tersebut bermula dari (tuduhan) pemerkosaan oleh pemuda Uighur terhadap perempuan Han. Alhasil, banyak korban meninggal dan luka-luka dari kedua belah pihak (Clarke 2010). Kerusuhan ini sejatinya merupakan puncak dari diskriminasi yang telah dilakukan oleh pemerintahan Tiongkok. Masalah imigrasi etnis Han Tiongkok yang turut dipromosikan negara menimbulkan berbagai macam masalah kesejahteraan terhadap etnis Uighur. Disparitas tercipta antara kedua kelompok tersebut, dengan posisi berat sebelah ke arah etnis Han Tiongkok. Hal ini seakan-akan menjadikan minoritas Uighur sebagai masyarakat kelas dua (Furtun 2010; Felicia 2013). 
Kekerasan berbasis etnik ini lantas memicu kritik dan kecaman besar di kalangan masyarakat internasional terhadap pemerintah Tiongkok (Furtun 2010). Kendati demikian, Tiongkok senantiasa berdalih bahwa apa yang dilakukannya merupakan bentuk respon terhadap pemberontakan dan ekstrimisme yang memiliki dukungan dari kelompok teror seperti Al-Qaeda. Namun, dalam Konferensi Tingkat Tinggi (KTT) Asia-Pacific Economic Cooperation (APEC) tahun 2001, Presiden George W. Bush menyatakan bahwa konflik Uighur sejatinya merupakan konflik berbasis etnis dan sosial. Karena itu, alasan Tiongkok yang menjustifikasikan langkahnya sebagai bentuk dari perang melawan teror tidak dapat dibenarkan (Furtun 2010).

Meskipun berbagai kritik-dan bahkan kecaman-senantiasa dilontarkan, otoritas Partai Komunis tetap melanjutkan praktik diskriminasi dan prosekusi tersebut. Pada tahun 2017, pemerintah provinsi Xinjiang mengadopsi undang-undang anti-ekstremisme yang melarang orang untuk menumbuhkan jenggot panjang dan mengenakan kerudung di depan umum (Mahmut 2019; Soliev 2019). Hal ini lantas membatasi kebebasan ekspresi kultural dan identitas dari minoritas Uighur. Tidak hanya itu, undang-undang juga menjadi landasan hukum bagi pendirian fasilitas-fasilitas "pusat pelatihan" untuk memerangi ekstremisme. Akibatnya, sekitar satu juta warga beretnis Uighur digiring untuk mengikuti proses "re-edukasi". Namun, banyak pihak memandang fasilitas-fasilitas tersebut sejatinya merupakan "kamp konsentrasi" untuk menghapus identitas Uighur dan dijalakannya proses asimilasi kultural budaya Han Tiongkok. Dari rentang bulan April 2017 hingga Agustus 2018, jumlah tersebut terus bertambah (Enos 2019; Maizland 2019).

Dari sekian reaksi yang ada, salah satu yang cukup prominen diutarakan oleh masyarakat Turki. Sentimen ini pun juga tercermin dalam hubungan bilateral Turki-Tiongkok. Pada masa pemerintahan Erdogan, hubungan bilateral dengan Negeri Tirai Bambu pada awalnya mengalami kedekatan. Hal ini terafirmasi dengan intensifnya kunjungan resmi antar kedua negara tersebut. Namun, keadaan berubah semenjak Kerusuhan Urumqi pecah. Erdogan bahkan menyatakan akan membawa konflik Uighur ke sidang Dewan Keamanan Persatuan Bangsa-bangsa (DK-PBB). Ketegangan pun mengikuti, meskipun tidak berlangsung lama. Pada bulan September hingga Oktober 2010, Turki kembali mendekati Tiongkok untuk meminta bantuan dalam pengembangan perekonomian (Kumara 2019). Tulisan ini lebih lanjut akan membedah inkonsistensi sikap dari pemerintah Turki tersebut dengan (1) memaparkan lebih rinci terkait konflik antara etnis Uighur dengan pemerintah Tiongkok, (2) memaparkan kadar solidaritas antara etnis Turki-Uighur, dan 
(3) menghubungkannya dengan respon pemerintah Turki terkait kekerasan pada etnis Uighur menggunakan kerangka diplomasi bilateral.

\section{Diplomasi Bilateral: Mengukur Hubungan Diplomatik Turki-Tiongkok}

Untuk membahas mengenai dinamika yang terjadi antara Tukri dan Tiongkok dalam masalah Uighur, penulis akan menggunakan kerangka konsep diplomasi bilateral. Diplomasi atau hubungan bilateral merupakan relasi yang terjalin di antara dua negara yang berdaulat dan mengacu kepada hubungan-hubungan dalam bidang politik, ekonomi, dan budaya (Financial Mechanism Comitee 2017). Hubungan bilateral ditandai dengan adanya kerja sama yang terjalin oleh kedua belah pihak. Elemenelemen yang dapat menjadi tolak ukur dari kuatnya suatu diplomasi bilateral meliputi: besarnya arus perdagangan dan investasi, intensitas aktivitas pertukaran pengetahuan dan budaya, serta timbulnya pemahaman dan kesadaran masyarakat dari kedua negara terkait dengan kedekatan diplomatis yang tercipta (ibid 2017). Hubungan bilateral dapat terjalin dengan renggang ataupun semakin erat. Semakin kuat relasi yang ada, maka kedudukan tiap negara akan menjadi semakin relevan di mata masing-masing (Rozental dan Buenrosto 2013). Kedua kemungkinan ini ditentukan oleh bagaimana tingkat komunikasi di antara kedua negara tersebut (Rana 2018). Karena itu, hubungan antara dua negara akan selalu berubah dari waktu ke waktu.

Terdapat dua cara bagaimana diplomasi bilateral dapat terjadi. Pertama, secara formal dengan mempertemukan kedua pihak, melalui perantara diplomat atau negosiator, dan duduk dalam satu ruangan untuk melakukan perundingan hingga mencapai titik di mana dihasilkan sebuah kesepakatan. Diplomasi bilateral dengan cara non-formal menjadi salah satu cara yang paling sering digunakan didalam menyelesaikan permasalahan ataupun kerja sama yang lebih erat. Kedua, secara non-konvensional atau mengutilisasikan cara-cara selain pertemuan formal untuk mencapai kesepakatan (Tarrosy 2014). Dengan demikian, kedua pihak tidak harus melakukan negosiasi dengan duduk di dalam satu ruangan yang sama, namun dapat ditempuh dengan pendekatanpendekatan informal seperti pertemuan makan siang atau melakukan aktivitas hiburan atau olahraga dengan sesama diplomat.

Masalah yang terjadi di Xinjiang dalam konteks ini lantas menjadi satu tantangan dalam hubungan bilateral antara Turki dan Tiongkok. Diskriminasi dan ketimpangan yang nampak memancing kemarahan Pemerintah Turki, hingga pada akhirnya Pemerintah Turki menaikkan isu ini ke dalam agenda DK-PBB (Israeli 2010). Dengan demikian, hal ini 
menandakan naiknya tensi antara kedua negara. Hubungan yang memanas seakan-akan mendingin beberapa tahun kemudian dengan adanya proses kerja sama antara pemerintah Turki dan Pemerintah Tiongkok dalam koridor Belt and Road Initiatives (BRI) yang sampai saat ini sudah membentang di banyak kota di Eropa (Kadilar dan Erguney 2017). Kebijakan yang memberikan banyak keuntungan bagi Turki ini lantas membuat sikap Turki semula terhadap Tiongkok dalam kasus Uighur kembali dipertanyakan.

\section{Magnitudo Ketegangan antara Etnis Uighur-Tiongkok}

Secara historis, konflik antara etnis Uighur dan Tingkok telah berlangsung lama. Wilayah yang kini dikenal sebagai Xinjiang dahulu merupakan bagian dari kekuasaan Kesultanan Ottoman-dengan nama East Turkestan-di Asia Tengah yang berbatasan langsung dengan Tiongkok (Felicia 2013). Namun seiring dengan terjadinya perubahan konstelasi kekuasaan, berbagai pihak mengklaim sebagai pemilik yang sah dari kawasan tersebut. Etnis Uighur, sebagai penduduk asli dari East Turkestan, menjustifikasikan klaim atas dasar sejarah, bahasa, dan kultur. Namun, pihak Tiongkok tidak mengakui hal tersebut. Pada 1884, Tiongkok mendeklarasikan East Turkestan sebagai bagain dari provinsinya dan mengubah nama wilayah tersebut menjadi Xinjiang, di artikan secara literal sebagai "perbatasan baru". Semenjak itu, kerusuhan kerapkali terjadi. Pasca-Perang Dunia II, masyarakat Uighur sempat merebut kembali kontrol atas wilayah tersebut. Namun, keberhasilan ini tidak berhasil lama seiring dengan masuknya Peoples Liberation Army (PLA) ke wilayah tersebut dan merestorasi kembali kendali di bawah Tiongkok (Furtun 2010).

Sejak awal kekuasaan Tiongkok pada tahun 1949, etnis Uighur mendapatkan banyak pelanggaran hak asasi dan hak sipil (Hidayat 2013). Masyarakat Uighur dipandang sebagai ancaman etno-nasionalis terhadap Tiongkok (Human Rights Watch Report 2005). Karena itu, meskipun Beijing mendeklarasikan wilayah Xinjiang sebagai daerah otonom, aktivitas di daerah tersebut di kontrol dengan ketat. Dalam kehidupan sosial, etnis Uighur yang mulanya menjadi mayoritas di Xinjiang perlahan tergusur oleh masuknya etnis Han Tiongkok melalui migrasi secara besar-besaran. Migrasi tersebut tentu saja dikampanyekan oleh pihak pemerintah Tiongkok. Hal ini dijustifikasikan dengan alasan untuk membantu Xinjiang lepas dari keterbelakangaan. Oleh karena itu, Tiongkok memacu dan mendorong lebih dari 800.00o intelektual dan tenaga profesional untuk berpindah ke daerah tersebut (State Council 2003). 
Tingkok juga memiliki aturan ketat mengenai kebebasan berekspresi, terlebih terkait dengan praktik beragama. Hal yang sama juga tercermin di wilayah Otonomi Uighur Xinjiang. Persepsi ancaman yang timbul dari pemerintah Tiongkok terhadap potensi separatisme membuat adanya penarikan hak beragama etnis Uighur yang mayoritas muslim. Beijing memandang bahwa ekstrimisme berkedok agama Islam menjadi alasan atas munculnya ancaman tersebut. Hal ini lantas menjadi justifikasi atas dilakukannya serangkaian tindakan keras untuk membatasi pergerakan komunitas Uighur. Upaya Tingkok untuk mengendalikan praktik beragama masyarakat Uighur begitu diperhatikan, hingga segala sistem sosial yang diterapkan di Xinjiang seakan-akan dirancang untuk sepenuhnya membentuk kembali identitas keagamaan dari komunitas Uighur, sebagaimana kedudukan dari agama-terlebih agama Islammenjadi komponen yang krusial dalam formasi identitas dan budaya Uighur (Human Rights Watch Report 2005).

Kebijakan kebebasan beragama Tiongkok juga seringkali tidak konsisten dalam sejarahnya. Pada era Revolusi Budaya Mao Ze Dong, seluruh tempat ibadah diubah secara paksa menjadi tempat publik. Di Xinjiang, pemerintah Tingkok bahkan mengubah halaman masjid menjadi tempat penyembelihan babi (Hidayat 2013). Pada era keterbukaan Deng Xiao Ping di antara dekade 1970-1980-an kebebasan beragama sedikit melonggar. Keadaan kembali mengeras pada tahun 1996 ketika Tingkok mengkampanyekan Strike Hard Policy yang secara khusus menindak tegas praktik spiritisme dan kegiatan keagamaan ilegal (Human Rights Watch Report 2005). Sebagai salah satu perwujudan dari kampanye tersebut, pada 1998 pemerintah pusat Tingkok meminta pemerintah Xinjiang memperketat kebijakan terkait kegiatan keagamaan (Hidayat 2013). Mulai dari 1996 hingga 2003, Amnesty International mencatat terdapat lebih dari 200 hukuman mati di Xinjiang sebagai akibat dari kampanye Strike Hard Policy. Bahkan, hanya sebagian kecil dari hukuman mati yang diliput oleh media. Angka keseluruhan yang tidak diungkapkan diklasifikasikan sebagai rahasia negara (Human Rights Watch Report 2005).

Isu separatisme, identitas, agama, dan budaya, yang digaungkan antara etnis Uighur dan Tiongkok lantas memunculkan ketimpangan ekonomi (Maizland 2019). Human Rights Organizations telah mengamati bahwa manfaat ekonomi dari sumber daya ekstraksi dan pembangunan sering kali dinikmati secara tidak proporsional; dengan bobot paling besar dirasakan oleh etnis Han Tiongkok. Hal ini menyebabkan etnis Uighur semakin terpinggirkan (Maizland 2019). Tidak hanya itu, banyak warga Uighur mengeluh tentang diskriminasi ras dan diskriminasi etnis 
minoritas yang kerap kali terjadi, mereka tidak memiliki kesempatan yang sama dalam pendidikan, perawatan kesehatan, dan pekerjaan. (Amnesty International 1999).

Pelanggaran HAM berat juga telah dan sedang terjadi di Xinjiang, sebagaimana jutaan orang dari etnis Uighur ditahan secara sewenangwenang. Penindasan ini meningkat secara signifikan pada tahun 2017 (Lehr dan Bechrakis 2019). Orang-orang etnis Uighur, kelompok etnis beragaman Muslim lain, serta sejumlah kelompok agama minoritas lainnya ditahan tanpa persidangan dan dilarang berkomunikasi dengan siapapun. Tingkok menyebut tindakan ini sebagai upaya "re-edukasi" dan "pelatihan vokasional" dengan tujuan untuk menumpas bibitbibit ekstrimisme, terlebih mengingat Kerusuhan Uruqmi yang sempat terhadi sebelumnya. Namun, sejumlah laporan mengindikasikan bahwahal ini sejatinya merupakan upaya penghapusan identitas dan asimilasi minoritas ke dalam masyarakat Han Tiongkok. Beijing yakin bahwa langkah-langkah ini akan memperkuat loyalitas kaum minoritas kepada Partai Komunis dan pada akhirnya mewujudkan "harmoni" di wilayah tersebut (Lehr dan Bechrakis 2019).

Segala prosekusi dan diskriminasi yang dilakukan oleh pemerintah Tiongkok ini tidak sepenuhnya didasari atas faktor ideologis dan identitas, maupun keamanan saja. Terdapat pula motif yang lebih pragmatis di dalamnya. Tidak dapat dipungkiri bahwa Xinjiang memang merupakan wilayah penghubung penting dalam agenda BRI. Xinjiang merupakan rumah bagi cadangan batu bara dan gas alam terbesar di Tiongkok. Dengan demikian, penghapusan segala potensi separatisme akan membuat pengembangan wilayah Xinjiang menjadi lebih optimal. Upaya ini telah dicanangkan semenjak tahun 1954. Di bawah kepemimpinan Mao Zedong, Tiongkok mendirikan Xinjiang Production and Construction Corps (XPCC) atau biasa disebut Bingtuan. Instansi ini unik dan memiliki status khusus yang mana XPPC dikelola secara independen dari pemerintah daerah Xinjiang, memiliki pasukan polisi, pengadilan dan penjara, perusahaan pertanian, kompleks industri, serta jaringan kamp kerja tersendiri. XPCC bahkan memiliki wewenang untuk mengambil wilayah manapun di Xinjiang, termasuk daerah selatan yang dianggap sebagai jantung budaya, dan tempat tinggal komunitas orang Uighur, untuk kepentingannya (Amnesty International 1999). Selama bertahun-tahun, unit polisi bersenjata XPCC telah memiliki andil besar dalam memadamkan kerusuhan etnis di wilayah tersebut. 


\section{Saudara Tua: Solidaritas antara Etnis Turki dengan Uighur}

Uighur merupakan salah satu etnis yang menempati sebuah wilayah di Asia Tengah sejak abad ke-9 M. Wilayah ini dikenal dengan nama Turkistan Timur atau Uighur-land. Karena adanya proksimitas geografis ini, etnis Uighur termasuk ke dalam rumpun bangsa Turki yang berimplikasi pada adanya kesamaaan dialek kebahasaan dengan bahasa Turki (Sopyan 2019). Tidak hanya itu, etnis Turki dan Uighur juga disatukan oleh identitas primordial yang sama. Selain dalam hal linguistik, ikatan pun turut timbul dari kesamaan budaya dan agamaterlebih dalam payung agama Islam-yang telah lama menjalin (Kumara 2019). Dalam konteks yang lebih kontemporer, hubungan inijuga didukung dengan dengan persebaran populasinya di negara-negara Turkik lain seperti Kazakhstan, Kirgzstan, dan Uzbekistan.

Terciptanya hubungan ini dapat diatribusikan pada perjalanan sejarah yang terjalin dari era Kekaisaran Timuriah dan Kesultanan Ottoman. Pada masa ini, penyebaran pengaruh kultural dari orang-orang Turki ke Asia tidak dapat dilepaskan dari peranan Timur Lenk, seorang penguasa berdarah Turko-Mongol yang memerintah suatu wilayah yang terbentang dari Turki bagian Tenggara, Suriah, Irak, Kuwait dan Iran, serta meliputi wilayah-wilayah di Asia Tengah yaitu Kazhakstan, Afghanistan, Armenia, Azerbaijan, Georgia, Turkmenistan, Uzbekistan, Kyrgiztan, Pakistan, India Utara-Barat, dan wilayah Kasghar/Xinjiang di Tiongkok (Fermalasari 2015). Kelangsungan dari peradaban multikultur ini kemudian berlanjut di era Dinasti Turki Usmani.

Etnis Uighur sangat berbeda dengan mayoritas masyarakat TiongkokHan Tiongkok-dari berbagai aspek, baik dari segi fisik, budaya serta keagamaannya. Han Tiongkok lebih mirip dengan perawakan orang Asia sedangkan Uighur lebih mirip orang Eropa Kaukasus. Etnis Uighur mengucapkan dialek bahasa Turki dan menganggap bahwa bahasa Mandarin adalah bahasa asing. Uighur berbagi tradisi budaya yang sangat kental dengan masyarakat etnis Turkik dan komunitas etnis beragama Muslim dan hanya memiliki sedikit kesamaan dengan Etnis Han (Mackerras 1994). Lantas, proksimitas identitas yang lebih besar dengan masyarakat Turki pada akhirnya memunculkan sebuah tenggang rasa di antara keduanya. Keduanya memiliki sejarah panjang sebagai "saudara tua”. Sehingga, ketika terdapat konflik yang melibatkan salah satu di antaranya, pihak yang lain akan menanggapi sebagai wujud solidaritas. 


\section{Bilateralisme Turki-Tiongkok: Respon Turki atas Perundungan Etnis Uighur}

\section{Sekilas Mengenai Hubungan Turki-Tiongkok}

Hubungan diplomatik Ankara-Beijing dimulai secara resmi sejak 1971. Meskipun belum terdapat aktivitas konkret antar kedua negara yang tersebut, tahun tersebut diyakini sebagai cikal-bakal dari hubungan bilateral di antara keduanya (Selcuk 2013). Pada tahun 1990, TurkiTiongkok menjalin kerjasama militer terbatas (Soylemez 2017; Slijper 2017). Hal ini dilatarbelakangi oleh pembatasan ekspor persenjataan oleh negara-negara Barat terhadap Turki. Bagi negara-negara tersebut, ekspor alutsista dianggap terlalu rentan dan beresiko karena pemerintah Turki tengah bersitegang dengan Kurdistan Workers' Party pada saat itu (Philips 2007; Jongerden \& Akkaya 2012). Kerjasama ini lantas menjadi respon alternatif Ankara untuk memenuhi kebutuhan alutsista dalam negeri mereka (Lavi dan Lindenstrauss 2016).

Memasuki awal abad ke-21, Turki berupaya untuk merancang ulang postur kebijakan luar negerinya, sehingga dapat bergerak dengan lebih independen dan mengurangi ketergantungan aspek pertahanan pada Barat. Selaras dengan ini, pelbagai upaya dilakukan untuk mencapai hubungan yang lebih baik dengan Tiongkok. Hubungan bilateral kedua negara tersebut semakin erat. Bahkan, Ankara dan Beijing pernah melakukan latihan bersama di pangkalan udara Konya (Lavi dan Lindenstrauss 2016). Turki juga terlibat dalam inisiasi dialogue partner dalam kerangka Shanghai Cooperation Organization yang digagas oleh Rusia dan Tiongkok (Atli 2016; Tekir 2017; Yildirimcakar 2019).

\section{Tarik-Ulur Solidaritas antar "Saudara Tua"}

Namun, sejak Kerusuhan Uruqmi tahun 2009, hubungan keduanya berubah drastis (Kumara 2019). Dengan adanya ikatan etnisitas yang telah terafiliasi sangat kuat antara Uighur dan Turki, berbagai permasalahan yang menyangkut Uighur tentu akan berimbas kepada hubungan bilateral Ankara-Beijing. Pasca terjadinya kerusuhan pada Juli 2009, Kementerian Luar Negeri Turki langsung merespon permasalahan tersebut. Turki berharap bahwa aktor dibalik perundungan tersebut dapat segera ditangkap dan diadili. Turki juga mengingatkan Tingkok bahwa perlu adanya tindakan untuk mencegah terjadinya kembali peristiwa semacam itu di masa yang akan datang (Uslu 2009). Tidak lama setelah itu, Perdana Menteri (PM) Turki, Recep Tayyip Erdogan turut bersuara dengan mengatakan bahwa insiden tersebut merupakan semacam genosida (Israeli 2010; Lavi dan Lindenstrauss 2016; Soyelemez 
2017). Respon dari pemerintah Turki ini memicu gejolak kemarahan Tiongkok. Mengingat Turki merupakan anggota tidak tetap dari DK-PBB periode 2009-2011 pada saat itu, langkah lebih jauh bahkan dilakukan Erdogan dengan membawa isu ini menjadi agenda pembahasan rapat (Israeli 2010). Namun, Tiongkok sebagai anggota tetap menolak ide tersebut dengan menggunakan hak veto yang dimilikinya (Wulandari 2017).

Kerusuhan tersebut tidak hanya mengundang respon dari pemerintah Turki, namun juga masyarakat Turki. Publik Turki melakukan demonstrasi secara terpusat di Caglayan Square, Istanbul. Demonstrasi yang digagas oleh organisasi East Turkestan Culture and Solidarity Association ini menuntut pemerintah Turki untuk merespon penindasan yang menimpa etnis Uighur di XUAR. Solidaritas antar kedua etnis terasa dengan antusiasme para demonstran yangs sebagian besar membawa serta bendera Turki dan menyerukan ikatan etnis, budaya, dan agama antara Turki dan Uighur (Felicia 2013). Tidak hanya itu, gerakan protes dan solidaritas erupa yang dilakukan oleh serikat buruh dan asosiasi bisnis Turki bahkan melangkah lebih jauh lagi dengan mendesak pemerintah untuk memboikot produk asal Tingkok diseluruh negeri(Israeli 2010). Wujud solidaritas ini bukan pertama kalinya ditunjukan oleh Turki. Sebelumnya, Turki pernah memberlakukan open-door policy bagi komunitas Uighur yang mulai berdatangan dari Tiongkok. Pada tahun 1952, ketika beberapa ribu orang Uighur meninggalkan rezim komunis Tingkok ke Pakistan, pemerintah Turki turun tangan dengan memberikan suaka dan pengungsian kepada 1.850 orang ke Turki (Israeli 2010).

Tensi pun mulai diredam ketika Menteri Dalam Negeri Turki Zafer Caglayan mengadakan pertemuan diplomatik dengan Menteri Luar Negeri Tingkok Yang Jiechi pada 30 Agustus 2009. Setelah pertemuan tersebut, Caglayan menyampaikan kepada wartawan bahwa selain membahas hubungan antara Ankara-Beijing, Ia juga menyampaikan pandangan Turki mengenai kerusuhan yang terjadi di Urumqi pada bulan Juli lalu. Menteri Luar Negeri Tingkok menanggapi pernyataan Caglayan dengan baik dan memaparkan kepadanya tentang langkah-langkah apa yang akan diambil setelah peristiwa tersebut. Pertemuan ini dapat dikatakan sebagai bentuk upaya diplomasi bilateral konvensional dari Turki untuk turut serta menyelesaikan permasalahan dan memenuhi permintaan masyarakat Turki yang geram akan perilaku pemerintah Tiongkok terhadap Uighur (Soleymez 2017).

Relasi antara Turki-Tiongkok cenderung menunjukkan tren naikturun pada masa-masa berikutnya. Namun, tidak ada yang sampai 
menimbulkan krisis diplomatis yang cukup signifikan. Pada tahun 2014, Tiongkok menyatakan kemarahannya mengenai kebijakan migrasi dari Turki yang terkesan ambigu. Kebijakan tersebut cenderung memberikan kemudahan bagi masyarakat etnis Uighur untuk memasuki wilayah Turki. Bagi Beijing, kelonggaran mobilitas ini menimbulkan kekhawatiran tersendiri, sebagaimana akses melalui Turki akan memudahkan para ekstrimis untuk bergabung pada kelompok teroris, terlebih kelompok Islamic State (IS). Indikasi terhadap masalah ini mulai timbul dengan tingginya emigrasi etnis Uighur dari Tiongkok dalam beberapa bulan setelah pemberlakuannya (Lavi dan Lindenstrauss 2016). Dengan mulai terpukul-mundurnya IS pada tahun 2017, masalah baru timbul terkai dengan repatriasi militan IS yang terdampar di Timur-Tengah dan Turki, yang mana beberapa di antaranya juga meliputi sejumlah etnis Uighur. Bagi Beijing, hal ini menjadi ancaman baru. Namun, kekhawatiran ini telah berhasil diminimalisir oleh Ankara, sehingga hubungan bilateral Turki-Tiongkok relatif tidak terganggu (Soleymez 2017).

Ketengangan kembali muncul pada tahun 2015 ketika beredar laporan palsu yang menuduh pemerintah Tingkok telah membunuh Muslim Uighur yang sedang berpuasa di bulan Ramadhan (Lavi dan Lindenstrauss 2016; Soleymez 2017). Kesalahpahaman ini menciptakan kemarahan masyarakat Turki. Sejumlah aksi protes pun diadakan dan didukung oleh beberapa media konservatif dan/atau pro-pemerintah (Soleymez 2017). Meskipun terdapat kegusaran di kalangan publik, peristiwa ini tidak menimbulkan ketegangan besar di tingkat diplomatis. Beriringan dengan dimulainya era Erdogan sebagai Presiden, krisis ini pun berhasil diatasi dengan matang hingga membuatnya tidak berlangsung lama (Soleymez 2017).

\section{Pragmatisme Kepentingan Ekonomi dan Masa Depan Solidaritas Uighur-Turki}

Merujuk pada beberapa kasus yang telah dipaparkan, dapat diketahui bahwa meskipun simpati publik masih terus berlangsung untuk etnis Uighur, pemerintahan Ankara memiliki pertimbangan tersendiri mengenai konsekuensi apa yang dapat ditimbulkan apabila sikap pertentangan yang diciptakannya ini terus didengungkan terhadap relasinya dengan Beijing (Israeli 2010). Hal cukup logis meningat Tiongkok merupakan mitra impor terbesar ketiganya. Begitu pula dengan signifikansi kedudukan Turki bagi Tiongkok yang menduduki peringkat ke-20 negara target impornya pada tahun 2009 (Athilla 2010). Dengan kata lain, terdapat isu terkait interdependensi kompleks yang juga terlibat dalam permasalahan ini. 
Konsiderasi pragmatis ini menjadi semakin prominen di era Presiden Erdogan. Dari titik ini, mulai timbul kesadaran di antara elit politik Turki bahwa kerjasama ekonomi merupakan faktor penting yang perlu dipertimbangkan (Lavi dan Lindenstrauss 2016). Katalis dari kemunculan pemikiran ini adalah agenda investasi infrastrutkur besar-besaran dalam koridor BRI yang dapat dipandang sebagai bentuk diplomasi ekonomi dari Tiongkok. Turki secara tidak langsung memiliki kepentingan pragmatis dalam inisiasi ini. Pada Oktober 2015, serangkaian jalur kereta api berkecepatan tinggi baru antara Turki, Georgia, dan Azerbaijan diluncurkan sebagai buah karya dari perusahaan kereta api milik Tiongkok dan perusahaan swasta Turki. Sebagai proyek lanjutan dari pembangunan jalur kereta api tersebut (Kars-Tbilisi-Baku), Turki juga tertarik pada bantuan Tiongkok untuk membangun kereta api berkecepatan tinggi di dalam negeri yang menghubungkan wilayah Turki timur dan barat (Kars-Edirne).

Sebagai bentuk ekstensi dari kerjasama dalam kordior BRI, Turki turut disertakan pula menjadi adalah salah satu dari 50 anggota pendiri Asian Infrastructure Investment Bank (AIIB) yang diluncurkan oleh Tiongkok (Soleymez 2017). Berbagai investasi lain ke Ankara juga semakin digalakkan oleh Beijing. Wakil Perdana Menteri Tiongkok membahas masalah ini dengan perwakilan dari Turki pada sebuah pertemuan di Shanghai (Lavi dan Lindenstrauss 2016). Dan hasilnya, dalam beberapa tahun terakhir, investasi asing langsung foreign direct investment (FDI) Tiongkok di Turki mulai meningkat (Soleymez 2017). Kebergantungan kedua negara terhadap impor energi pun mendorong adanya proyek energi bersama; ditunjukkan dengan keterlibatan Tiongkok sebagai mitra strategis agenda pembangunan reaktor nuklir yang diinisiasi oleh Turki (Lavi dan Lindenstrauss 2016).

Semenjak intensifnya hubungan ekonomi tersebut, hubungan TurkiTiongkok menjadi semakin menghangat. Pada tahun 2015, presiden Turki berjanji pada presiden Tiongkok bahwa Ankara tidak akan mengizinkan siapa pun memanfaatkan wilayah Turki untuk melakukan hal-hal yang membahayakan kepentingan dan keamanan nasional Tiongkok. (Soleymez 2017). Pada tahun 2016, sebelum KTT G20 Hangzhou, kedua negara menandatangani Memorandum of Understanding (MoU) sebagai simbol atas diformulasikannya kerjasama BRI di Turki, yang mana mencakup pembangunan Turki sebagai "Koridor Tengah". Dalam kunjungan lanjutan Erdogan ke Tiongkok setelah adanya kesepakatan ini, kedua negara menetapkan target yang sangat ambisius, yakni akan mencapai volume perdagangan sebesar 100 miliar USD pada tahun 2020 (Soleymez, 2017). 
Diplomasi bilateral ekonomi Ankara-Beijing terus berkembang dari tahun ke tahun. Lambat-laun, hal ini pada akhirnya membuat isu mengenai Uighur, yang mana pada awalnya cukup keras didengungkan, menduduki kursi paling belakang dalam daftar prioritas kebijakan luar negeri Turki. Hingga pada Juli 2019, Turki berkomitmen untuk tetap dan terus memiliki hubungan bilateral yang erat dengan Tiongkok. Hal ini dibuktikan dengan pernyataan presiden Erdogan kepada media setelah bertemu dengan presiden Tiongkok Xi Jinping:

"Turki akan senantiasa mengikuti One China Policy dan mengafirmasi kondisi dari orang-orang yang tinggal di Xinjiang, termasuk Uighur, yang sejatinya telah 'hidup bahagia'. Namun, masih sulit bagi mereka untuk mengakui bahwa alasan utama di balik kemakmuran yang dirasakan di wilayah tersebut adalah karena peranan dari Pemerintah Tiongkok. Ankara tidak akan membiarkan masalah apa pun yang terjadi di Xinjiang merusak hubungan bilateral dengan Beijing” (Kumara 2019). 


\section{Kesimpulan}

Berdasarkan kajian di atas, maka dapat diketahui bahwa respon dari Turki terhadap permasalahan etnis Uighur yang pada awalnya didengungkan dengan cukup keras dapat diatribusikan pada besarnya ikatan identitas dan besarnya rasa solidaritas antara etnis Uighur dan Turki. Potensi ancaman terkait dengan separatisme dan destabilitas, serta dilengkapi pula dengan isu identitas dan kepentingan ekonomi pragmatis yang ada di kawasan Xinjiang membuahkan sebuah konflik berkepanjangan antara etnis Uighur dan Tiongkok. Ketegangan yang terjadi membuat kelompok minoritas Uighur semakin termaginalisasi dan terdiskriminasi dalam kehidupan bermasyarakat di Tiongkok. Lantas, tertariknya perhatian publik dan pemerintah Turki mengenai isu ini menjadi wujud dari solidaritas tersebut. Manifestasi dari kedekatan ini ditunjukan dengan adanya gerakan protes dan demonstrasi yang kerap kali dilakukan masyarakat Turki setiap terjadinya penindasan terhadap etnis Uighur. Dalam ranah yang lebih diplomatis, krisis ini mempengaruhi hubungan bilateral Ankara-Beijing. Pihak pemerintah Turki pun juga sempat memberikan kecaman keras terhadap tindakan Tiongkok pada saat itu. Isu Uighur pada dasarnya memang selalu membayangi hubungan bilateral Turki-Tiongkok. Namun, seiring dengan semakin intensifnya diplomasi ekonomi bilateral antar kedua negara yang dikatalisasi oleh momentum BRI Tiongkok, kedua negara telah sepakat untuk tetap menjaga hubungan baik atas dasar pragmatisme. Hal ini pada akhirnya membuat isu Uighur semakin jauh dari prioritas kebijakan luar negeri Turki. 


\section{Daftar Pustaka}

\section{Buku dan Bagian dalam Buku}

Amensty International, 1999. Peoples Republic of China: Gross Violations of Human Rights in the Xinjiang Uighur Autonomous Region. Amnesty International: London.

Mackerras, C., 1994. China's Ethnic Minorities and Globalisation. London: Routledge.

Rana, K. S., 2018. The Encyclopedia of Diplomacy, New Jersey: John Wiley \& Sons, Ltd.

Rozental, A., dan Alicia Buenrostro, 2013. The Oxford Handbook of Modern Diplomacy. Oxford: Oxford University Press.

Sandikli, A., 2010. China: A New Super Power? Dimension of Power, Energy and Security. Istanbul: Bilgesam Publication.

\section{Artikel Jurnal}

Clarke, M., 2010. "China, Xinjiang and the internationalisation of the Uyghur issue", Global Change, Peace \& Security, 22(2): 213-229.

Felicia, A. S., 2013. "Etnisitas Dan Politik Luar Negeri: Respon Turki Terhadap Penindasan Etnis Uighur di Xinjiang", Jurnal Analisis Hubungan Internasional, 2(3): 295-317.

Hidayat, M. N., 2013. "Diaspora Uighur dan Hak Sipil di Xinjiang Cina". Jurnal Interdependence, 1(3): 165-179.

Israeli, R., 2010. "China's Uighur Problem”. Israel Journal of Foreign Affairs, 4(1): 89-101.

Kadilar, R., dan Erkin Erguney., 2017. "Belt and Road Initiatives: Perks and Challenge for Turkey". Turkey Policy Quarterly, 16(2).

Lavi, G., dan Gallia Lindenstrauss, 2016. "China and Turkey: Closer Relation Mixed with Suspicion”. Strategic Assesment, 19(2): 119-127

Selcuk, C., 2013. “Turkey-China: Rising Partnership.”, OrtadoguAnaliz, 5(52): 32-45.

\section{Skripsi dan Tesis}

Fermalasari, Z. F., 2015. "Keterlibatan Turki Dalam Konflik Xinjiang 
Tahun 2009”. Skripsi Sarjana. Yogyakarta: Departemen Hubungan Internasional, Universitas Muhammadiyah Yogyakarta.

Kumara, E. M., 2019. "The Dynamic of Turkey - China Relations In Uighur Issue (In The Era Of Erdogan 2009-2019)”. Skripsi Sarjana. Yogyakarta: Departemen Hubungan Internasional, Universitas Muhammadiyah Yogyakarta.

Wulandari, W., 2017. "Pengaruh Konflik Xinjiang Tahun 2009 Terhadap Hubungan Turki dan China”. Skripsi Sarjana. Yogyakarta: Departemen Hubungan Internasional, Universitas Muhammadiyah Malang.

\section{Laporan dan Publikasi Resmi}

Congressional Research Service Report. 2020. Uighurs in China 2020.

Full Text of White Paper on History and Development in Xinjiang. 2003. Beijing: The State Council of The People's Republic of China.

Human Rights Watch. 2005. "Devastating Blows: Religious Repression of Uighurs in Xinjiang”. HRIC Special Report.

\section{Artikel Daring}

Chung, C., 2002. "China's' War on Terror': September11 and Uighur Separatism". [daring]. Tersedia dalam [http://www.cfr.org/publication/4765/chinas war on terror.html] (Diakses pada [15 Mei 2020]).

Colakoglu, S., 2012. “Turkey-China Relations: Seeking A Strategic Partnership" [daring]. Tersedia dalam [http://Uighuramerican.org/ article/turkey-china-relations-seeking-strategic-partnership.html] (Diakses pada [8 April 2020]).

Furtun, F., 2010. "Turkish-Chinese Relations in the Shadow of the Uighur Problem" [daring]. Global Political Trends Center. Tersedia dalam [https://www.jstor.org/stable/resrep07712?seq=9\#metadata info tab contents] (Diakses pada [8 April 2020]).

Lehr, A.. K dan Mariefaye Bechrakis. 2019. "Connecting the Dots in Xinjiang: Forced Labor, Forced Assimilation, and Western Supply Chains" [daring]. Center for Strategic \& International Relations. Tersedia dalam [https://www.csis.org/analysis/connecting-dots-xinjiang-forced-labor-forced-assimilation-and-western-supply-chains] 
(Diakses pada 8 April 2020).

Maizland, L., 2019. "China's Repression of Uighurs in Xinjiang” [daring]. Tersedia dalam [https://www.cfr.org/backgrounder/chinas-repression-uighurs-xinjiang] (Diakses pada [15 Mei 2020]).

Soleymez, M., 2017. "Turkey and China: An Account of Bilateral Relations Evolution" [daring], Asia Centre. Tersedia dalam [https://centreasia. eu/en/turkey-and-china-an-account-of-a-bilateral-relations-evolution/] (Diakses pada [15 Mei 2020]).

Sopyan, I., 2019., "Uighur, Islam dan Pemerintahan China; Kekejaman Rezim Komunis di Balik Kemajuan Ekonomi China" [daring]. Tersedia dalam [https://www.persis.or.id/Uighur-islam-dan-pemerintahan-china-kekejaman-rezim-komunis-di-balik-kemajuan-ekonomi-china] (Diakses pada [3 Mei 2020]).

Uslu, E., 2009. "Ankara Anxiously Monitors the Xinjiang Crisis" [daring]. Eurasia Daily Monitor. Tersedia dalam [http://jamestown.org/program/ankara-anxiously-monitors-the-xinjiang-crisis/] (Diakses pada [16 Mei 2020]). 